\title{
PENGARUH KEPEMIMPINAN DEKAN TERHADAP KINERJA PEGAWAI PADA FAKULTAS KEGURUAN DAN ILMU PENDIDIKAN UNIVERSITAS MULAWARMAN
}

\author{
M.Z. Arifin \\ Dosen Ilmu Administrasi Publik FISIP Universitas Widya Gama Mahakam Samarinda \\ Kusmayadi \\ Dosen Ilmu Administrasi Publik FISIP Universitas Widya Gama Mahakam Samarinda \\ e-mail: nadar1683@gmail.com \\ Reny Maresty Anggriany \\ Alumni Ilmu Administrasi Publik FISIP Universitas Widya Gama Mahakam Samarinda
}

\begin{abstract}
Abstrak
Fakultas Keguruan dan Ilmu Pendidikan Universitas Mulawarman adalah lembaga yang menghasilkan para sarjana. Untuk menghasilkan para sarjana yang berkualitas tidak hanya dibutuhkan dosen dibidang Pendidikan namun dibarengi dengan Aparatur yang bekerja, tetapi diperlukan kinerja para pegawai yang mendukung administrasi. Jika kinerja pegawai dapat dijalankan dengan baik maka hal ini akan berdampak baik pada pencapaian tujuan organisasi. Oleh karena itu kepemimpinan sangat berperan penting dan perlu diperhatikan oleh seorang pemimpin. Adapun yang menjadi tujuan dalam penelitian ini berdasarkan bahasan penelitian dalam latar belakang di atas, sebagai upaya untuk untuk mengetahui pengaruh Kepemimpinan Dekan terhadap kinerja pegawai pada Fakultas Keguruan dan Ilmu Pendidikan Universitas Mulawarman dan menguji kebenaran hipotesis yang peneliti ajukan. Jenis penelitian ini adalah verifikatif atau causalitas, dengan populasi pegawai dilingkungan Fakultas Keguruan dan Ilmu Pendidikan Universitas Mulawarman sebanyak 55 orang yang terdiri dari PNS 30 orang dan Non PNS berjumlah 25 orang.
\end{abstract}

Hasil penelitian menunjukkan bahwa Kepemimpinan Dekan ternyata berpengaruh terhadap kinerja pegawai pada Fakultas Keguruan dan Ilmu Pendidikan Universitas Mulawarman. Hal ini dibuktikan dari korelasi data yang digunakan yakni koefisien korelasi Rank Spearman yang dibuktikan dengan hasil hitung sebesar 0,646 yang ternyata lebih besar dari rs tabel harga-harga kritis rs koefisien korelasi Rank Spearman yaitu 0,224 pada tingkat signifikansi 0,05 untuk tes satu sisi. Hipotesis yang telah peneliti rumuskan yakni hipotesis null ditolak dan hipotesis alternatif diterima kebenarannya dengan perkataan lain Kepemimpinan Dekan berpengaruh terhadap kinerja pegawai di Fakultas Keguruan dan Ilmu Pendidikan Universitas Mulawarman.

Kata Kunci: Kepemimpinan Dekan, Kinerja Pegawai, Fakultas Keguruan Dan Ilmu Pendidikan Universitas Mulawarman

\footnotetext{
Abstract

Faculty of Teacher Training and Education Mulawarman University is an institution that produces scholars. To produce qualified scholars is not only required lecturers in the field of Education but accompanied by apparatus that work, but it is necessary performance of employees who support the administration. If the performance of employees can be run well then this will have a good impact on the achievement of organizational goals. Therefore leadership is very important role and need to be considered by a leader. As for the purpose of this study based on the research in the background above, as an attempt to
} 
determine the influence of Leadership Dean on employee performance at the Faculty of Teacher Training and Education Mulawarman University and test the truth of the hypothesis that the researchers propose. The type of this research is verifikatif or causalitas, with the population of employees in the Faculty of Teacher Training and Education Mulawarman University as many as 55 people consisting of civil servants 30 people and Non PNS amounted to 25 people.

The results showed that the Dean's Leadership had an effect on employee performance at Faculty of Teacher Training and Education Mulawarman University. This is evidenced from the correlation of data used the correlation coefficient Rank Spearman is evidenced by the calculation of 0.646 which was larger than rs table of critical prices rs Rank Spearman correlation coefficient is 0.224 at the 0.05 significance level for one-sided test. The hypothesis that the researcher has formulated that the null hypothesis is rejected and the alternative hypothesis is accepted truthfully with other words. Leadership of Dean has an effect on the employee performance at Faculty of Teacher Training and Education Mulawarman University.

Keywords: Leadership Dean, Employee Performance, Faculty of Teacher Training and Education Mulawarman University

\section{Pendahuluan}

Fakultas Keguruan dan Ilmu Pendidikan Universitas Mulawarman adalah lembaga yang menghasilkan para sarjana. Untuk menghasilkan para sarjana yang berkualitas tidak hanya dibutuhkan dosen dibidang Pendidikan namun dibarengi dengan Aparatur yang bekerja, tetapi diperlukan kinerja para pegawai yang mendukung administrasi. Diharapkan para pegawai Fakultas Keguruan dan Ilmu Pendidikan dapat memberikan prestasi kerja yang mampu bekerja secara optimal tentang tugas pokok dan fungsi. Namun pada kenyataannya belum menunjukkan hasil yang optimal, bisa terlihat dari disiplin kerja yang masih kurang. Disadari lemahnya kinerja pegawai dipengaruhi banyak faktor antara lain semangat kerja yang rendah, masih kecilnya remunerasi, kurangnya motivasi yang dilakukan oleh pemimpin. Dari sekian faktor yang menyebabkan kurangnya kinerja pegawai diduga yang berpengaruh pada kepemimpinan, padahal kepemimpinan itu sangat diharapkan oleh pegawai untuk tercapainya tujuan suatu lembaga.

Kepemimpinan yang ada di Fakultas Keguruan dan Ilmu Pendidikan Universitas Mulawarman dipimpin oleh seorang Dekan yang membutuhkan kepemimpinan yang baik sehingga Fakultas Keguruan dan Ilmu Pendidikan Universitas Mulawarman dapat menciptakan pelayanan yang maksimal.

Oleh karena itu harus ada kemauan semua pihak untuk merubah ke arah yang lebih baik. Bersamaan dengan usaha-usaha untuk meningkatkan kualitas aparatur pemerintah, maka harus disertai dengan adanya pemimpin yang mempunyai komitmen tinggi terhadap tujuan organisasi. Karena dengan adanya komitmen yang tinggi seorang pemimpin dapat mendorong aparatur ke arah hasil kerja yang lebih baik.

Kata kepemimpinan biasanya sangat berhubungan erat dengan Atasan. Seorang Atasan biasanya disebut dengan pemimpin yang dapat mengelola sumber daya manusia yang ada dalam organisasi. Namun dalam menjalankan suatu kegiatan dalam organisasi tentu saja tidak mudah, karena pada saat menjalankannya tentu saja akan mengalami rintangan maupun hambatan. Hal ini biasanya di sebabkan oleh hubungan antara pimpinan dengan pegawai yang menyebabkan ketidak senangan pegawai maupun kesenangan pegawai terhadap pekerjaan. 
Seseorang yang telah ditunjuk sebagai pemimpin untuk memimpin bawahannya, dialah yang harus menjalankan fungsi organisasi itu sendiri yang menentukan atas berhasil tidaknya suatu organisasi. Kepemimpinan yang sukses menunjukkan bahwa pengelolaan suatu organisasi berhasil dilaksanakan dengan sukses juga. Setiap kemampuan dalam kepemimpinan harus melekat erat pada diri seorang pemimpin, apapun tanggung jawab yang harus diterimanya. Karena tanpa adanya kemampuan memimpin terlebih dalam hal mengelola sumber daya manusia, tidak memungkinkan seorang pemimpin berhasil dengan baik dalam melaksanakan tanggung jawabnya. Selain itu, pimpinan harus memahami dan menyadari bahwa tantangan terpenting yang dihadapi adalah bagaimana menerapkan sumber daya manusia tersebut secara tepat dalam situasi tertentu untuk mencapai hasil optimum berupa mutu sumber daya manusia yang memuaskan. Sikap dan gaya prilaku pemimpin sangat besar pengaruhnya terhadap organisasi yang dipimpinnya, hal ini dapat berpengaruh terhadap produktivitas organisasi. Seorang pemimpin harus memiliki suatu program dan berprilaku yang baik, sehingga kepemimpinan mempunyai peranan yang sangat penting sebagai kekuatan dinamika yang mendorong, memotivasi, dan mengkoordinasikan para pegawai dalam mencapai tujuan.

Kinerja dikonsepsikan sebagai prilaku seseorang dalam menetepkan sasaran kerja, pencapaian terget sasaran kerja, cara kerja dan sikap pribadi seseorang. Tercapainya tujuan organisasi hanya dimungkinkan karena upaya para pelaku yang terdapat dalam organisasi untuk berkinerja dengan baik. Seorang pegawai yang memiliki kinerja yang tinggi dan baik dapat menunjang tercapainya tujuan dan sasaran yang telah ditetapkan oleh organisasi. Untuk dapat memiliki kinerja yang tinggi dan baik, seorang pegawai dalam melaksanakan pekerjaannya harus memiliki keahlian dan ketrampilan yang sesuai dengan pekerjaan yang ditekuninya. Namun kadangkala pimpinan kerap kali memerintah para pegawainya dengan sesuka hati tanpa memperhatikan kondisi pegawai tersebut. Sehingga hal tersebut akan berdampak pada kinerja pegawai yang kurang baik. Ketidak mampuan pegawai menjalankan tugasnya sesuai dengan tanggung jawab mereka bukan disebabkan karena pegawai tersebut tidak mampu mengerjakan tugas tersebut dengan baik. Apabila kinerja pegawai kurang baik maka hal tersebut akan berdampak pada tugastugas yang harus dikerjakan oleh pegawai yang sudah menjadi tanggung jawab mereka.

Apabila kinerja pegawai dapat dijalankan dengan baik maka hal ini akan berdampak baik pada pencapaian tujuan organisasi. Oleh karena itu kepemimpinan sangat berperan penting dan perlu diperhatikan oleh seorang pemimpin. Dengan kepemimpinan yang sesuai maka seorang pemimpin harus dapat berkomunikasi dengan baik dan dapat bekerja sama dalam hal tugas dan tanggung jawab.

\subsection{Permasalahan}

Adapun yang menjadi permasalahan dalam penelitian ini yakni Apakah Kepemimpinan Dekan berpengaruh positif terhadap kinerja pegawai pada Fakultas Keguruan dan Ilmu Pendidikan Universitas Mulawarman?

\subsection{Tujuan}

Adapun yang menjadi tujuan dalam penelitian ini berdasarkan bahasan penelitian dalam latar belakang di atas, sebagai upaya untuk untuk mengetahui pengaruh Kepemimpinan Dekan terhadap kinerja pegawai pada Fakultas Keguruan dan Ilmu Pendidikan Universitas Mulawarman dan menguji kebenaran hipotesis yang peneliti ajukan. 


\section{Kerangka Teori}

\subsection{Kepemimpinan}

Berikut ini akan peneliti sajikan pendapat para ahli tentang Kepemimpinan. Definisi kepemimpinan menurut Veithzal Rivai (2006:2) "proses mempengaruhi dalam menentukan tujuan organisasi, memotivasi perilaku pengikut untuk mencapai tujuan, mempengaruhi untuk memperbaiki kelompok dan budayanya. Selain itu juga mempengaruhi interpretasi mengenai peristiwa-peristiwa para pengikutnya, pengorganisasian dan aktivitas-aktivitas untuk mencapai sasaran, memelihara hubungan kerjasama dan kerja kelompok, perolehan dukungan dan kerjasama dari orang-orang diluar kelompok atau organisasi."

Menurut Robbins (2006:432) "kepemimpinan adalah kemampuan untuk mempengaruhi kelompok menuju pencapaian sasaran". Sedangkan menurut Erni Tisnawati dan Kurniawan Saefullah (2005:255) "kepemimpinan adalah seseorang yang memiliki kemampuan untuk mempengaruhi prilaku orang lain tanpa menggunakan kekuatan, sehingga orang-orang yang dipimpinnya menerima dirinya sebagai sosok yang layak memimpin mereka."

Oleh karena itu kepemimpinan dapat diartikan sebagai suatu proses mempengaruhi dan mengarahkan para karyawannya dalam melakukan tugas atau pekerjaan yang telah diberikan kepada mereka dan hal ini merupakan potensi untuk mampu membuat orang lain (yang dipimpin) mengikuti apa yang dikehendaki pimpinannya.

\subsubsection{Gaya Kepemimpinan}

Berikut ini akan peneliti sajikan pendapat para ahli tentang Gaya Kepemimpinan. Gaya kepemimpinan menurut Sutikno (2014:35) mengatakan gaya kepemimpinan atau perilaku kepemimpinan atau sering disebut Tipe Kepemimpinan. Tipe kepemimpinan yang luas dikenal dan diakui keberadaanya adalah sebagai berikut :

\section{Tipe Otokratik}

Tipe kepemimpinan ini menganggap bahwa kepemimpinan adalah hak pribadinya (pemimpin), sehingga ia tidak perlu berkonsultasi dengan orang lain dan tidak boleh ada orang lain yang turut campur. Seorang pemimpin yang tergolong otokratik memiliki serangkaian karateristik yang biasanya dipandang sebagai karakteristik yang negatif.Seorang pemimpin otokratik adalah seorang yang egois. Seorang pemimpin otokratik akan menunjukan sikap yang menonjolakan keakuannya, dan selalu mengabaikan peranan bawahan dalam proses pengambilan keputusan, tidak mau menerima saran dan pandangan bawahannya.

\section{Tipe Kendali Bebas atau Masa Bodo (Laisez Faire)}

Tipe kepemimpinan ini merupakan kebalikan dari tipe kepemimpinan otokratik. Dalam kepemimpinan tipe ini sang pemimpin biasanya menunjukkan perilaku yang pasif dan seringkali menghindar diri dari tanggung jawab. Seorang pemimpin yang kendali bebas cenderung memilih peran yang pasif dan membiarkan organisasi berjalan menurut temponya sendiri. Disini seorang pemimpin mempunyai keyakinan bebas dengan memberikan kebebasan yang seluas-luasnya terhadap bawahan maka semua usahanya akan cepat berhasil.

3. Tipe Paternalistik

Persepsi seorang pemimpin yang paternalistik tentang peranannya dalam kehidupan organisasi dapat dikatakan diwarnai oleh harapan bawahan kepadanya. Harapan bawahan berwujud keinginan agar pemimpin mampu 
berperan sebagai bapak yang bersifat melindungi dan layak dijadikan sebagai tempat bertanya dan untuk memperoleh petunjuk, memberikan perhatian terhadap kepentingan dan kesejahteraan bawahannya.Pemimpin yang paternalistik mengharapkan agar legitimasi kepemimpinannya merupakan penerimaan atas peranannya yang dominan dalam kehidupan organisasi.

4. Tipe Kharismatik

Seorang pemimpin yang kharismatik memiliki karakteristik khusus yaitu daya tariknya yang sangat memikat, sehingga mampu memperoleh pengikut yang sangat besar dan para pengikutnya tidak selalu dapat menjelaskan secara konkrit mengapa orang tersebut itu dikagumi.Hingga sekarang, para ahli belum berhasil menemukan sebab-sebab mengapa seorang pemimpinmemiliki kharisma.Yang diketahui ialah bahwa pemimpin yang demikian mempunyai daya penarik yang amat besar.

5. Tipe Militeristik

Pemimpin tipe militeristik berbeda dengan seorang pemimpin organisasi militer.Pemimpin yang bertipe militeristik ialah pemimpin dalam menggerakan bawahannya lebih sering mempergunakan sistem perintah, senang bergantung kepada pangkat dan jabatannya, dan senang kepada formalitas yang berlebihlebihan.Menuntut disiplin yang tinggi dan kaku dari bawahannya, dan sukar menerima kritikan dari bawahannya.

6. Tipe Pseudo-demokratik

Tipe ini disebut juga kepemimpinan manipulatif atau semi demokratik. Tipe kepemimpinan ini ditandai oleh adanya sikap seorang pemimpin yang berusaha mengemukakan keinginan-keinginannya dan setelah itu membuat sebuah panitia, dengan berpura-pura untuk berunding tetapi yang sebenarnya tiada lain untuk mengesahkan saran-sarannya. Pemimpin seperti ini menjadikan demokrasi sebagai selubung untuk memperoleh kemenangan tertentu.Pemimpin yang bertipe pseudo-demokratik hanya tampaknya saja bersikap demokratis padahal sebenarnya dia bersikap otokratis.Pemimpin ini menganut demokrasi semu dan lebih mengarah kepada kegiatan pemimpin yang otoriter dalam bentuk yang halus, samar-samar.

7. Tipe Demokratik

Tipe demokratik adalah tipe pemimpin yang demokratis, dan bukan kerena dipilihnya sipemimpin secara demokratis. Tipe kepemimpinan dimana pemimpin selalu bersedia menerima dan menghargai saran-saran, pendapat, dan nasehat dari staf dan bawahan, melalui forum musyawarah untuk mencapai kata sepakat. Kepemimpinan demokratik adalah kepemimpinan yang aktif, dinamis, dan terarah. Kegiatan-kegiatan pengendalian dilaksanakan secara tertib dan bertanggung jawab. Pembagian tugas disertai pelimpahan wewenang dan tanggung jawab yang jelas, memungkinkan setiap anggota berpartisipasi secara aktif.

\subsubsection{Fungsi dan Sifat Kepemimpinan}

Berikut ini akan peneliti sajikan pendapat para ahli tentang fungsi dan sifat kepemimpinan. Menurut Amirullah (2015:166) terdapat lima fungsi kepemimpinan yang hakiki, yaitu:

a) Fungsi penentu arah 
Keterbatasan sumber daya organisasi mengharuskan pemimpin utnuk mengelola dengan efektif, dengan kata lain arah yang hendak dicapi oleh organisasi menuju tujuannya yang harus sedemikian rupa sehingga mengoptimalkan pemanfaatan dari segala sasaran dan perasaan yang ada. Arah yang dimaksud tertuang dalam strategi dan taktik yang disusun oleh pimpinan dalam organisasi.

b) Fungsi sebagai juru bicara

Fungsi ini mengarahkan seorang pemimpin untuk berperan sebagai penghubung antara organisasi dengan pihak-pihak luar yang berkepentingan seperti pemilik saham, pemasok, penyalur, lembaga keuangan, dan instansi pemerintah yang terkait.

c) Fungsi sebagai komunikator

Fungsi pemimpin sebagai komunikator lebih ditekankan pada kemampuannya untuk mengkomunikasikan sasaran-sasaran, strategi, dan tindakan yang harus dilakukan oleh bawahan.

d) Fungsi sebagai mediator

Konflik-konflik yang terjadi atau adanya perbedaan-perbedaan kepentingan dalam organisasi menuntuk kehadiran seorang pemimpin dalam menyelesaikan permasalahan yang ada.Jadi, kemampuan menjalankan fungsi kepemimpinan selaku mediator yang rasional, obyektif, dan netral merupakan salah satu indikator ektifitas kepemimpinan seseorang.

e) Fungsi sebagai integrator

Adanya pembagian tugas, sistem alokasi daya dan tenaga, serta diperlukannya spesialisasi pengetahuan dan keterampilan dapat menimbulkan sikap, prilaku, dan tindakan berkotak-kotak dan oleh karenanya tidak boleh dibiarkan berlangsung terusmenerus. Dengan kata lain diperlukan integrator (pimpinan)terutama pada hirarki puncak organisasi.

\subsubsection{Kinerja Pegawai}

Berikut ini akan peneliti sajikan pendapat para ahli tentang kinerja pegawai. Menurut Anwar Prabu (2013 : 67) "kinerja Pegawai adalah prestasi kerja atau hasil kerja baik kualitas maupun kuantitas yang dicapai sumber daya manusia persatuan periode waktu dalam melaksanakan tugas kerjanya sesuai dengan tanggung jawab yang diberikan kepadanya."

Menurut Widodo (2001:28) "bahwa kinerja merupakan suatu hasil kerja yang dapat dicapai oleh seseorang atau kelompok orang dalam suatu organisasi, sesuai dengan wewenang dan tanggung jawab masing-masing dalam rangka mencapai tujuan organisasi yang bersangkutan secara legal, tidak melanggar hukum dan sesuai dengan moral dan etika."

Menurut Sedarmayanti (2001:21) "kinerja pegawai erat kaitannya dengan efektivitas kerja. Kinerja pegawai sebagaimana yang dikemukakan diatas menunjukkan adanya pencapaian terhadap hasil melalui adanya kebijakan, prosedur dan kondisi lingkungan organisasi."

Dari pengertian diatas dapat disimpulkan bahwa kinerja merupakan hasil dari proses pekerjaan tertentu secara terencana pada waktu dan tempat dari karyawan serta organisasi bersangkutan. 


\subsubsection{Tahapan Manajemen Kinerja Pegawai}

Menurut Sjafri dan Aida (2007:154) tahapan-tahapan pelaksanaan manajemen kinerja pegawai meliputi hal-hal berikut yaitu :

1) Tahapan Perencanaan kinerja

Perencanaan kinerja dilakukan pada tahap awal dari keseluruhan proses manajemen kinerja. Pada tahapan awal organisasi harus menetapkan tujuan dan sasaran kinerja, kriteria kinerja, dan indikator sebagai bentuk komitmen kinerja.

2) Tahapan Pelaksanaan Kinerja

Tahapan pelaksanaan kinerja merupakan implementasi tanggung jawab manajer untuk melakukan pengorganisasian, pengoordinasian, pengendalian, pendelegasian, dan pengarahan kerja kepada bawahannya

3) Tahapan penilaian kinerja

Penilaian kinerja digunakan untuk mengetahui sejauh mana tujuan perjanjian organisasi telah dicapai.Idealnya, penilaian kinerja tidak hanya dilakukan oleh manajer, tetapi bawahan hendaknya juga diberi peluang untuk terlibat agar mereka dapat melakukan konfirmasi dengan penilaian kinerja yang dilakukan oleh manajernya.

4) Tahapan Perbaikan Kinerja

Tahapan perbaikan kinerja merupakan tahapan pembaharuan dan perjanjian ulang penetapan kembali akuntanbilitas kinerja yang harus dipenuhi oleh pegawai: revisi tujuan, terget kinerja, standar kinerja, dan revisi kriteria kinerja. Pemimpin perlu melakukan pembaharuan tujuan dan rencana kegiatan untuk menjaga agar organisasi tidak kehilangan arah tujuan.

\subsubsection{Faktor-Faktor Yang Mempengaruhi Kinerja Pegawai}

Menurut Sjafri dan Aida (2007 : 155) Kinerja merupakan suatu konstruktur multidimensi yang mencakup banyak faktor yang mempengaruhinya. Faktor-faktor tersebut diantaranya adalah :

1) Faktor personal/individual, meliputi unsur pengetahuan, keterampilan, kemampuan, kepercayaan diri, motivasi, dan komitmen yang dimiliki oleh setiap individu karyawan.

2) Faktor kepemimpinan, meliputi aspek kualitas manajer dan teamleader dalam memberikan dorongan, semangat, arahan, dandukungan kerja pada karyawan.

3) Faktor tim, meliputi kualitas dukungan dan semangat yang diberikan oleh rekan dalam satu tim, kepercayaan terhadap sesama anggota tim, kekompakan, dan keeratan anggota tim.

4) Faktor sistem, meliputi sistem kerja, fasilitas kerja atau infrastruktur yang diberikan oleh organisasi, proses organisasi, dan kultur kinerja dalam organisasi.

5) Faktor kontekstual, meliputi tekanan dan perunahan lingkungan eksternal dan internal.

Menurut Anwar Prabu (2013:67) faktor yang mempengaruhi pencapaian kinerja adalah :

a) Faktor kepemimpinan 
Secara psikologis, kemampuan terdiri dari kemampuan potensi dan kemampuan reality. Artinya pemimpin dan karyawan yang memiliki IQ di atas rata-rata dengan pendidikan yang memadai untuk jabatannya dan terampil dalam mengerjakan pekerjaan sehari-hari, maka akan lebih mudah mencapai kinerja maksimal.

b) Faktor motivasi

Motivasi diartikan suatu sikap pimpinan dan karyawan terhadap situasi kerja dilingkungan organisasi. Mereka yang bersikap positif terhadap situasi kerjanya akan menunjukkan motivasi kerja tinggi dan sebaliknya jika mereka bersikap negatif terhadap situasi kerjanya akan menunjukkan motivasi kerja yang rendah.

Menurut Amirullah (2015 : 232) berkenaan dengan faktor-faktor yang mempengaruhi kinerja:

1) Kinerja baik dipengaruhi 2 faktor:

a) Internal (pribadi) yang meliputi kemampuan tinggi dan kerja keras.

b) Eksternal (lingkungan) yang meliputi pekerjaan mudah, nasib baik, bantuan dari rekan-rekan dan pimpinan yang baik.

2) Kinerja jelek dipengaruhi 2 faktor:

a) Internal (pribadi) terdiri dari kemampuan rendah, dan upaya sedikit.

b) Eksternal (lingkungan) terdiri dari pekerjaan sulit, nasib buruk, rekan-rekan kerja tidak broduktif, dan pemimpin yang tidak simpatik.

Dengan demikian ada beberapa cara-cara untuk meningkatkan kinerja pegawai diantaranya adalah :

1) Diagnosis

Suatu diagnosa yang berguna dapat dilakukan secara informal oleh setiap individu yang tertarik untuk meningkatkan kemampuannya dalam mengevaluasi dan memperbaiki kinerja. Teknik-teknik yang digunakan yaitu: refleksi, mengobservasi kinerja, mendengarkan komentar-komentar orang lain tentang apa yang sedang terjadi dalam suatu pekerjaan.

2) Pelatihan

Pelatihan dapat membantu manajemen bahwa pengetahuan yang diperoleh dapat digunakan dengan tepat.

3) Tindakan

Tidak ada program dan pelatihan yang dapat mencapai hasil sepenuhnya tanpa dorongan untuk menggunakannya.

\subsection{Hipotesis}

Pada penelitian ini digunakan 2 (dua) hipotesis yaitu hipotesis alternatif dan hipotesis nol, keduanya itu akan dibuktikan dengan jalan analisis data dan pengujian hipotesis, hipotesis yang dimaksud adalah :

1. Diduga Kepemimpinan Dekan berpengaruh terhadap kinerja pegawai di Fakultas Keguruan dan Ilmu Pendidikan Universitas Mulawarman (Ha)

2. Diduga Kepemimpinan Dekan tidak berpengaruh terhadap kinerja pegawai di Fakultas Keguruan dan Ilmu Pendidikan Universitas Mulawarman (Ho)

\subsection{Definisi Operasional}


Untuk membuktikan kebenaran hipotesis, maka diperlukan definisi operasional sebagai indikator variabel, yakni:

1. Kepemimpinan sebagai independen variabel dengan indikator sebagai berikut :

a. Tingkat kemampuan dalam menggerakkan pegawai/bawahan

b. Tingkat kemampuan dalam mencapai tujuan

c. Tingkat kemampuan dalam mencapai hasil kerja

2. Kinerja pegawai sebagai dependen variabel dengan indikator sebagai berikut

a. Tingkat kualitas pekerjaan (mutu)

b. Tingkat kuantitas pekerjaan (jumlah)

c. Tingkat kecepatan dalam menyelesaikan pekerjaan

\section{Metode}

Berdasarkan permasalahan dan tujuan penelitian, maka jenis penelitian ini adalah verifikatif atau causalitas, dengan populasi pegawai dilingkungan Fakultas Keguruan dan Ilmu Pendidikan Universitas Mulawarman sebanyak 55 orang yang terdiri dari PNS 30 orang dan Non PNS berjumlah 25 orang. Mengingat kemampuan peneliti maka seluruh PNS dan Non PNS akan dilibatkan menjadi sampling. Dengan demikian peneliti tidak menggunakan sample dalam penelitian ini. Artinya seluruh PNS dan Non PNS yang berjumlah 55 orang dilibatkan (sensus) sebagai responden.

Dengan analisis data menggunakan korelasi Rank Spearman digunakan untuk mencari hubungan atau untuk menguji signifikasi hipotesis asosiatif bila masing - masing variabel yang dihubungkan berbentuk ordinal, dan sumber data antar variabel tidak harus sama (Sugiyono, 2004:305).

1. Apabila tidak ditemukan himpunan yang berangka sama maka dipergunakan rumus sebagai berikut :

$$
r_{s}=1-\frac{6 \sum d_{i}{ }^{2}}{n\left(n^{2}-1\right)}
$$

2. Apabila ditemukan himpunan yang berangka sama maka akan digunakan rumus seperti dibawah ini

$$
r_{s}=\frac{\sum x^{2}+\sum y^{2}-\sum d_{i}^{2}}{2 \sqrt{\sum x^{2} \sum y^{2}}}
$$

Dimana :

$$
\sum y^{2}=\frac{n^{3}-n}{12}-\sum T_{y} \quad \sum x^{2}=\frac{n^{3}-n}{12}-\sum T_{x}
$$

Kemudian untuk mengoreksi jumlah kuadrat dengan mempertimbangkan angka sama, maka peneliti akan menggunakan faktor koreksi $\mathrm{T}$, dengan rumus sebagai berikut :

$$
\mathrm{T}=\frac{\mathrm{t}^{3}-\mathrm{t}}{12}
$$

Keterangan : 


$$
\begin{aligned}
\Upsilon \mathrm{s} & =\text { koefisien korelasi Rank Spearman } \\
\sum \mathrm{x}^{2} & =\text { jumlah kudrat variabel } \mathrm{x} \\
\sum \mathrm{y}^{2} & =\text { Jumlah kuadrat variabel } \mathrm{y} \\
\sum \mathrm{di}^{2} & =\text { jumlah kuadrat hasil selisih ranking } \mathrm{x} \text { dan } \mathrm{y} \\
\mathrm{n} \quad & =\text { jumlah responden yang diambil. } \\
\mathrm{T} & =\text { faktor koreksi bagi angka sama } \\
\mathrm{n} & =\text { jumlah variabel yang mempunyai angka sama } \\
12 & =\text { bilangan tetap }
\end{aligned}
$$

Dengan demikian dapat diketahui apabila koefisien korelasi yang diperoleh lebih besar dari Ys tabel dengan tingkat signifikansi 0,05 untuk uji satu sisi, maka dapat disimpulkan bahwa terdapat pengaruh yang positif diantara kedua variabel. Akan tetapi jika sebaliknya bahwa $\Upsilon_{s}$ tabel lebih besar dari $\Upsilon_{s}$ empiris untuk tes satu sisi, maka hipotesis yang diajukan ditolak.

\section{Hasil}

\subsection{Gambaran Umum Lokasi}

Fakultas Keguruan dan Ilmu Pendidikan Universitas Mulawarman merupakan pusat kajian Ilmu-ilmu kependidikan yang mempunyai beberapa kelebihan dalam bidang pendidikan dibanding dengan lembaga pendidikan sejenis yang ada di Kalimantan Timur. Sebagai pusat kajian ilmu-ilmu kependidikan yang mempunyai nilai tambah dalam posisi dan peran Fakultas Keguruan dan Ilmu Pendidikan Universitas Mulawarman yang sangat strategis yaitu membantu pemerintah Propinsi Kalimantan Timur terutama dalam penyediaan tenaga-tenaga guru, karena itu berbagai upaya yang dijalankan untuk menyiapkan peserta didik menjadi anggota masyarakat yang memiliki kemampuan akademik yang dapat menerapkan, mengembangkan ilmu pengetahuan, teknologi dan mengupayakan penanggulangannya untuk meningkatkan kualitas sumber daya manusia serta tenaga-tenaga pendidik yang potensial.

Fakultas Keguruan dan Ilmu Pendidikan diawali dengan dibentuknya presidium yang bernama presidium IKIP Samarinda pada tahun 1972, kemudian secara resmi menyatakan diri bergabung dengan Universitas Mulawarman dengan melebur menjadi salah satu fakultas. Fakultas Keguruan dan Ilmu Pendidikan Universitas Mulawarman telah melewati sebuah perjalanan panjang sebagai fakultas yang mengemban amanah pada penyelenggaraan tri darma perguruan tinggi bidang pendidikan di daerah, dan Fakultas Keguruan dan Ilmu Pendidikan Universitas Mulawarman sampai saat ini masih menjadi salah satu fakultas favorit yang memiliki jumlah mahasiswa besar serta menjadi rujukan dalam penyelenggaraan pendidikan di Provinsi Kalimantan Timur dan Kalimantan Utara. Ini berarti bahwa Fakultas Keguruan dan Ilmu Pendidikan Universitas Mulawarman menjadi salah satu sub-sistem dari keseluruhan system penyelenggaraan pendidikan di daerah maupun nasional.

Tugas pokok dan fungsi Fakultas Keguruan dan Ilmu Pendidikan adalah menyelenggarakan kegiatan Tri Dharma Perguruan Tinggi di bidang pendidikan, penelitian dan pengabdian pada masyarakat mulai jenjang sarjana (S1), magister (S2) dan doctor (S3) serta dalam bidang profesi Keguruan dan Ilmu Pendidikan. 


\subsection{Hasil indikator kepemimpinan}

1. Tingkat kemampuan dalam menggerakkan pegawai/bawahan.

a. Berdasarkan hasil yang diperoleh dari pengolahan data yang telah diuraikan pada bagian sebelumnya pada pertanyaan pertama mengenai tingkat kemampuan dalam menggerakkan pegawai/bawahan dapat dijelaskan sebagai berikut : $87,28 \%$ responden menyatakan mampu, $12,27 \%$ responden menyatakan kurang mampu. Hasil ini menunjukkan bahwa kemampuan pimpinan dalam menggerakkan pegawai/bawahan artinya pimpinan mampu menggerakkan pegawai dalam bekerja, tetapi masih terdapat masalah sebesar $12,27 \%$ pegawai yang menyatakan bahwa pimpinan kurang mampu dalam menggerakkan pegawai/bawahan dalam bekerja, untuk hal ini sebaiknya pimpinan perlu lebih banyak mengkoordinasikan kepada pegawai agar para pegawai mau mengikuti apa yang diarahkan oleh pimpinannya tersebut.

b. Berdasarkan hasil yang diperoleh dari pengolahan data yang telah diuraikan pada bagian sebelumnya pada pertanyaan mengenai tingkat kemampuan dalam memberikan arahan dalam bekerja dapat dijelaskan sebagai berikut : 72,72\% responden menyatakan selalu, 27,28\% responden menyatakan kadang-kadang. Hasil ini menunjukkan bahwa kemampuan pimpinan dalam memberikan arahan dalam bekerja bahwa pimpinan selalu memberikan arahan pegawai dalam bekerja, tetapi masih terdapat masalah sebesar $27,28 \%$ pegawai yang menyatakan bahwa pimpinan kadang-kadang mampu dalam memberikan arahan dalam bekerja, untuk hal ini sebaiknya pimpinan perlu lebih banyak memberikan arahan dan pembinaan kepada pegawai agar para pegawai mendapat arahan yang baik dari pimpinan dalam bekerja.

2. Tingkat kemampuan dalam mencapai tujuan

a. Berdasarkan hasil yang diperoleh dari pengolahan data yang telah diuraikan pada bagian sebelumnya pada pertanyaan mengenai kemampuan pimpinan dalam memberikan arahan sebelum melaksanakan tugas/pekerjaan untuk mencapai tujuan dapat dijelaskan sebagai berikut : $72,72 \%$ responden menyatakan selalu, $27,28 \%$ responden menyatakan kadang-kadang. Hasil ini menunjukkan bahwa kemampuan pimpinan dalam memberikan arahan sebelum melaksanakan tugas/pekerjaan bahwa pimpinan selalu memberikan arahan pegawai dalam melaksanakan tugas/pekerjaan untuk mencapai tujuan, tetapi masih terdapat masalah sebesar $27,28 \%$ pegawai yang menyatakan bahwa pimpinan kadangkadang dalam memberikan arahan dalam bekerja, untuk hal ini sebaiknya pimpinan perlu lebih banyak memberikan arahan dan mengevaluasi kepada pegawai agar para pegawai mendapat arahan yang baik dari pimpinan dalam melaksanakan tugas/pekerjaan yang diberikan.

b. Berdasarkan hasil yang diperoleh dari pengolahan data yang telah diuraikan pada bagian sebelumnya pada pertanyaan mengenai kemampuan pimpinan dalam memberikan contoh bekerja yang baik untuk mencapai tujuan dapat dijelaskan sebagai berikut : 69,10\% responden menyatakan selalu, 30,90\% responden menyatakan kadang-kadang. Hasil ini menunjukkan bahwa kemampuan pimpinan dalam memberikan contoh bekerja yang baik untuk mencapai tujuan bahwa pimpinan cukup memberikan contoh bekerja yang baik untuk mencapai tujuan, karena masih terdapat masalah sebesar 30,90\% pegawai yang menyatakan bahwa pimpinan kadang-kadang dalam memberikan contoh bekerja yang baik dalam bekerja untuk mencapai tujuan, untuk hal ini sebaiknya pimpinan perlu lebih banyak memberikan contoh bekerja yang baik kepada pegawai agar para 
pegawai mampu mengerjakan pekerjaan yang baik pula dalam bekerja agar hasil yang dicapai sesuai dengan tujuan yang diinginkan.

3. Tingkat kemampuan dalam mencapai hasil kerja

a. Berdasarkan hasil yang diperoleh dari pengolahan data yang telah diuraikan pada bagian sebelumnya pada pertanyaan mengenai kemampuan pimpinan dalam mendorong prestasi kerja bagi pegawai dapat dijelaskan sebagai berikut : 74,54\% responden menyatakan selalu, 25,46\% responden menyatakan kadang-kadang. Hasil ini menunjukkan bahwa pimpinan selalu mendorong prestasi kerja bagi pegawai dalam mencapai hasil kerja, namun masih terdapat masalah sebesar $25,46 \%$ pegawai yang menyatakan bahwa pimpinan kadang-kadang dalam memberikan dorongan prestasi kerja dalam mencapai hasil kerja, untuk hal ini sebaiknya pimpinan perlu lebih banyak memberikan dorongan prestasi kerja bagi pegawai agar dapat mencapai hasil kerja yang baik.

b. Berdasarkan hasil yang diperoleh dari pengolahan data yang telah diuraikan pada bagian sebelumnya pada pertanyaan mengenai kemampuan pimpinan menjadi reviewer dalam hasil pekerjaan dapat dijelaskan sebagai berikut : 67,28\% responden menyatakan sering, 32,72\% responden menyatakan kadang-kadang. Hasil ini menunjukkan bahwa pimpinan cukup sering menjadi reviewer dalam hasil pekerjaan, karena masih terdapat masalah sebesar $32,72 \%$ pegawai yang menyatakan bahwa pimpinan kadang-kadang dalam menjadi reviewer dalam hasil pekerjaan, untuk hal ini sebaiknya pimpinan perlu lebih banyak memberikan tindak lanjut dalam hasil pekerjaan agar dapat mencapai hasil kerja yang baik.

\subsection{Hasil indikator kinerja pegawai}

1. Tingkat kualitas pekerjaan (mutu)

a. Berdasarkan hasil yang diperoleh dari pengolahan data yang telah diuraikan pada bagian sebelumnya pada pertanyaan mengenai tingkat kualitas pekerjaan (mutu) dalam mengerjakan pekerjaan sesuai standar mutu yang ditetapkan oleh lembaga dapat dijelaskan sebagai berikut : 94,54\% responden menyatakan sesuai, 5,46\% responden menyatakan kurang sesuai. Hasil ini menunjukkan bahwa lebih dari 90\% pegawai memilih skor 3 yang berarti bahwa mereka dikatakan sesuai standar mutu dalam mengerjakan pekerjaan.

b. Berdasarkan hasil yang diperoleh dari pengolahan data yang telah diuraikan pada bagian sebelumnya pada pertanyaan mengenai tingkat kualitas pekerjaan (mutu) dalam mengerjakan pekerjaan dengan efektif dan efisien artinya tepat waktu dan sesuai dengan tugas yang diberikan pimpinan dapat dijelaskan sebagai berikut : $85,46 \%$ responden menyatakan selalu, $14,54 \%$ responden menyatakan kadangkadang. Hasil ini menunjukkan bahwa lebih dari $80 \%$ pegawai memilih skor 3 yang berarti bahwa mereka dikatakan selalu mengerjakan pekerjaan dengan efektif dan efisien artinya tepat waktu dan sesuai dengan tugas yang diberikan pimpinan.

2. Tingkat kuantitas pekerjaan (jumlah)

a. Berdasarkan hasil yang diperoleh dari pengolahan data yang telah diuraikan pada bagian sebelumnya pada pertanyaan mengenai tingkat kuantitas pekerjaan (jumlah) dalam mengerjakan beban (bobot) tugas yang diberikan dapat diselesaikan dapat dijelaskan sebagai berikut : 83,63\% responden menyatakan dapat, $16,37 \%$ responden menyatakan kadang-kadang. Hasil ini menunjukkan 
bahwa lebih dari $80 \%$ pegawai memilih skor 3 yang berarti bahwa mereka dikatakan selalu menyelesaikan beban (bobot) tugas yang diberikan.

b. Berdasarkan hasil yang diperoleh dari pengolahan data yang telah diuraikan pada bagian sebelumnya pada pertanyaan mengenai tingkat kuantitas pekerjaan (jumlah) dalam mengerjakan beban (bobot) tugas yang diberikan dapat dikerjakan dengan baik dapat dijelaskan sebagai berikut : 74,54\% responden menyatakan selalu, 25,46\% responden menyatakan kadang-kadang. Hasil ini menunjukkan bahwa lebih dari $70 \%$ pegawai memilih skor 3 yang berarti bahwa mereka dikatakan selalu menyelesaikan beban (bobot) tugas dengan baik.

3. Tingkat kecepatan dalam menyelesaikan pekerjaan.

a. Berdasarkan hasil yang diperoleh dari pengolahan data yang telah diuraikan pada bagian sebelumnya pada pertanyaan mengenai tingkat kecepatan dalam menyelesaikan pekerjaan sesuai dengan waktu yang ditentukan dapat dijelaskan sebagai berikut : $83,63 \%$ responden menyatakan selalu, $16,37 \%$ responden menyatakan kadang-kadang. Hasil ini menunjukkan bahwa lebih dari $80 \%$ pegawai memilih skor 3 yang berarti bahwa mereka dikatakan selalu menyelesaikan tugas-tugas yang diberikan sesuai dengan waktu yang telah ditentukan.

b. Berdasarkan hasil yang diperoleh dari pengolahan data yang telah diuraikan pada bagian sebelumnya pada pertanyaan mengenai tingkat kecepatan dalam menyelesaikan pekerjaan yang diberikan lebih cepat dari waktunya agar dapat mengerjakan tugas berikutnya dapat dijelaskan sebagai berikut : 58,19\% responden menyatakan selalu, 41,81\% responden menyatakan kadang-kadang. Hasil ini menunjukkan bahwa pegawai cukup berusaha dalam menyelesaikan tugas-tugas yang diberikan lebih cepat agar dapat mengerjakan tugas berikutnya, karena masih terdapat masalah sebesar $41,81 \%$ pegawai yang menyatakan bahwa kadang-kadang menyelesaikan tugas-tugas yang diberikan lebih cepat agar dapat mengerjakan tugas berikutnya, untuk hal ini sebaiknya pimpinan perlu lebih banyak memberikan tindak lanjut dalam hasil pekerjaan agar dapat mencapai hasil kerja yang baik.

\section{Simpulan}

1) Kepemimpinan Dekan ternyata berpengaruh terhadap kinerja pegawai pada Fakultas Keguruan dan Ilmu Pendidikan Universitas Mulawarman. Hal ini dibuktikan dari korelasi data yang digunakan yakni koefisien korelasi Rank Spearman yang dibuktikan dengan hasil hitung sebesar 0,646 yang ternyata lebih besar dari rs tabel harga-harga kritis rs koefisien korelasi Rank Spearman yaitu 0,224 pada tingkat signifikansi 0,05 untuk tes satu sisi.

2) Hipotesis yang telah peneliti rumuskan yakni hipotesis null ditolak dan hipotesis alternatif diterima kebenarannya dengan perkataan lain Kepemimpinan Dekan berpengaruh terhadap kinerja pegawai di Fakultas Keguruan dan Ilmu Pendidikan Universitas Mulawarman.

3) Berdasarkan hasil penelitian menunjukkan bahwa kepemimpinan Dekan berpengaruh terhadap kinerja pegawai pada Fakultas Keguruan dan Ilmu Pendidikan Universitas Mulawarman, dengan demikian maka teori yang menjadi dasar / landasan dalam penelitian ini terbukti kebenarannya. 


\section{Daftar Pustaka}

AMIRULLAH. 2015. Pengantar Manajemen. Jakarta. Penerbit: Mitra Wacana Media.

ANWAR PRABU MANGKUNEGARA. 2013. Evaluasi Kinerja SDM. Bandung . Penerbit: PT.Refika Aditama

BAMBANG PRASETYO, dan LINA MIFTAHUL JANNAH. 2005. Metode Penelitian Kuantitatif: Teori dan Aplikasi. Jakarta: Penerbit PT.Raja Grafindo Persada.

ERNI TISNAWATI dan KURNIAWAN SAEFULLAH. 2014. Pengantar Manajemen. Jakarta. Penerbit : PRENADAMEDIA GROUP.

HADARI NAWAWI. 2007 . Metode Penelitian Bidang Sosial. Yogyakarta : Gajahmada University Pres

HANI HANDOKO. 2003. Manajemen. Cetakan Kedelapanbelas. BPFE Yogyakarta, Yogyakarta.

JOKO SUBAGYO. P. 2006. Metode Penelitian Dalam Teori Dan Praktek. Rineka Cipta. Jakarta.

LEXY J. MOLEONG. 2010, Metodologi penelitian kualitatif, Remaja Rosdakarya, Bandung

MURTI SUMARNI dan SALAMAH WAHYUNI, 2005, “ Metodologi Penelitian Bisnis", Penerbit Andi, Yogyakarta.

SEDARMAYANTI 2001. Sumber Daya Manusia dan Produktivitas Kerja. Jakarta: Mandar Maju.

SINGARIMBUN MASRI dan SOFIAN EFFENDI. 2006. Metode Penelitian Survei, Penerbit : Pustaka LP 3ES Indonesia, Jakarta

SJAFRI MANGKUPRAWIRA dan AIDA VITAYALA HUBEIS. 2007. Manajemen Mutu Sumber Data Manusia. Ciawi Bogor : Penerbit Ghalia Indonesia.

SOERJONO SOEKANTO. 2006. Sosiologi Suatu Pengantar, PT. Raja Grafindo Persada, Jakarta

STEPHEN P. ROBBINS, 2006. Perilaku Keorganisasian Jilid 1 Edisi 9. Jakarta: PT Indeks kelompok Gramedia

SUGIYONO. 2014. Metode Penelitian Manajemen. Bandung. Penerbit: CV. Alfabeta.

2012. Metode Penelitian Kuantitatif Kualitatif. Bandung. Penerbit : CV. Alfabeta 2004 Metode Penelitian Bisnis. Bandung. Penerbit : CV. Alfabeta 2010 Metode Penelitian Kuantitatif Kualitatif. Bandung. Penerbit: CV. Alfabeta

SUTIKNO, SOBRY M. 2014. Pemimpin Dan Gaya Kepemimpinan, Edisi Pertama Lombok: Holistica.

SUTRISNIO HADI, 2004, Metodologi Research Jilid I dan III, Penerbit Andi Offcet, Yogyakarta.

SYARIFUDIN HIDAYAT dan SEDARMAYANTI. 2002. Metodologi Penelitian. Bandung : Mandar Maju 
USMAN dan P.S AKBAR. 2003. Metodologi Penelitian Sosial. Jakarta: Bumi Aksara. . 2006. Pengantar Statistika. Jakarta: Bumi Aksara.

VEITHZAL RIVAI. 2006. Kepemimpinan dan Perilaku Organisasi. Penerbit PT. RajaGrafindo Persada: Jakarta.

WIRAWAN. 2013. Kepemimpinan. Jakarta. Penerbit : PT. Raja Grafindo Persada 